\title{
DOLMEN'S DECORATION PATTERNS IN SUMBA, INDONESIA
}

\section{Haris Sukendar}

Keywords: megalithic; dolmen; ornament; prehistory; archaeology

\section{How to Cite:}

Sukendar, H. (1987). DOLMEN'S DECORATION PATTERNS IN SUMBA,

INDONESIA. Berkala Arkeologi, 8(2), 1-16. https:// doi.org/10.30883/jba.v8i2.488

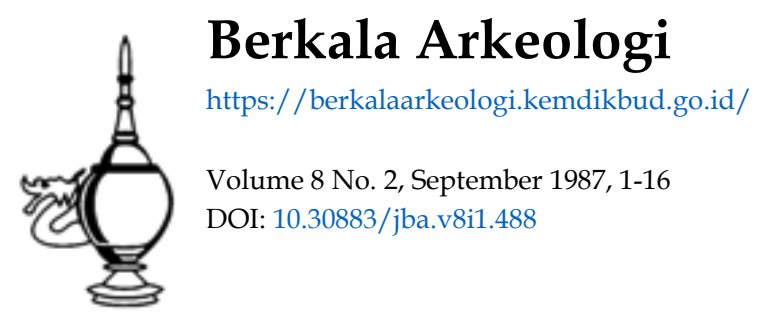




\section{DOLMENS DECORATION PATTERNS IN SUMBA, INDONESIA}

Haris Sukendar

\section{Introduction}

In his article, An Introduction to a unique Culture of Sumba, H.B. Mude assumed that the first settlers of Sumba came by boat from Malaka, Singapore, Riau, Java, Bali, Bima, Rote and Sabu, under the leadership of Umbu Mandoku and his wife, Rambu Humba. To honour his wife, the island was named Humba or Sumba. Sumba consists of West and East Regency. The climate is relatively hot with short rainy season and prolonged dry period. Sumba is a typical karst region, and bordered by the alluvial plain of Melolo areas, from where the river Melolo now flows eastward.

The Megalithic monuments (dolmens) of Sumba are widely spread. The dolmen are especially found in Kawangu, Rindiumalolo, Pau, Kaliuda, etc (East Sumba), and Tarung, Makatakere, etc (West Sumba). According to Sumbanese belief, someone's life (born, live, and die) was given by the Creator, God's will. Therefore, parents of newborn babies are required to sacrify something for their Creator and ancestor through many kinds of ritual activities, just to show their thankfulness for having newcoming babies. The megalithic dolmen in Sumba is found close to the village, in association with penji (upright stone), and usually connected with the burial ceremony. The village of Marapu people are often built in a square or round form, with it's dolm!en and penji (made of a great stone). Most of the dolmens of Sumba are dolmen like graves, and often placed around the village square. Their village, sometimes, consists of one street with dolmen like graves between the houses. The megalithic dolmens between the houses. The megalithic dolmens in Sumba are "the living megalithic traditions" which were still being used up to the present and they were made of smooth and well worked stones. Detail descriptions and documentations of the dolmens in Sumba 
were given by the team from The National Research Centre of Archaeology in 1981 and 1983, led by Haris Sukendar. Based on the study of these megalithic remains, they supposed that all the dolmens were used as burials. According to Van Heekeren, the "older" culture of dolmen were used as sacrificial altars or as memorials; while menhirs, obelisks of wood or stone, sometimes in rows or circles, and intervening spaces were often being used as meeting or dancing places. On the other hand, Von Heine Geldern said that the megalithic are connected with special notions concerning life after death; and that the majority are erected in the course of rites destined to protect the soul from the dangers believed to threaten in the underworld or on its way there........."

There are many decoration patterns on dolmen which were very similar to prehistoric decorations. The living megalithic dolmen's in Sumba were still being erected up to the present. The decorations were sculptured on the altars (stone table). Their forms differ from one to another, each having its own name. Its consists, mainly. of circles placed in a row. The circles are filled up with rossetes and other figures. The other motives are double spiral or S-shaped. tumpal. The very interesting decorations are human and animal figures. In searching for the meaning of dolmen's decorations, it is necessary to trace back into history, and even prehistory period. The significance of the dolmen's decoration cannot easily be explained, for sometimes people who use certain kind of decoration does not know its actual purpose. The study of the dolmen's decorations from the living megalithic tradition is to understand their meaning, function, and background. Through primitive decorations, it is expected that their inner vitality and spiritual background can be known. It could be possible that the prehistoric decorations, which were found in dolmens from Sumba islands, appeared at about $1500 \mathrm{BC}$, when their ancestors, began to migrate on this archipelago. From their original country in South $\mathrm{Cina}$, they reached the west and east coasts of Further India and finally they came to the area that now is known as Indonesia. Those ancient Indonesians 
lived in prehistoric period; they made polished stone tools. The second migration came in the palaeometallic period, when bronze objects were already nicely decorated. In many of these designs, a good deal of use is made of the S-shaped spiral or double spiral, the swastika, meander. In his Indonesian ornamental design, Van der Hoop said that in Indonesia, especially in the prehistoric and historic period, were found the decoration patterns taken from nature that have already used in the earliest art period, the neolithic age (Van der Hoop, 1949). Prehistoric designs found on dolmens can be classified as follow:

- geometric design,

- naturalistic design, such as parts of the human body, floral and faunal design.

- designs which cannot be classified under any of the previous groups.

In the living megalithic tradition, the decoration pattern on the dolmens were used as symbols and intended to avert evil, and to bring happines and fertility. In the bronze iron age, the designs tend to come more to the fore. The cloth depicted coming from Sumba and ancient cloth ornamented from Krui and Lake Ranau, were dominated by prehistoric ornaments. The swastika decoration, tumpal and circle decoration, double spiral, S-shaped etc. are the universal designs. In Nias, the circle in row position was known as vahasara dede, means that the unity and the tumpal decoration was "neofulayo" of the symbol of power.

\section{Human figure decoration}

The most beautiful and interesting dolmen's decorations came from East Sumba. The altars (stone table) found in Kawangu were decorated with 4 faces of human figure which was sculptured at the end of the altars. The characteristic of the human faces are very damaged. The mouths are wide. The eyes are slanting and the ears are big. The human ales are very similar to the mask found on the tympanon of kettledrum. On the biggest dolmen from Makatakere ornament (west Sumba) a human figure was curved in low relief. 
It was a woman with arms streched upwards and legs spread out, with wide mouth, thick lips, round eyes and a broad nose. Human decoration was found by Purusa Mahaviranata when he excavated the istone cist grave at Batu Tering. The decoration were found on the lid. In 1977 R.P. Soejono mentioned that the lid of sarcophagi are usually decorated with human and animal Figure (R.P. Soejono, 1977).

In the prehistoric period, the human figure decoration were meant for protection from the evil, and the depiction of ancestors. Many scholars said that human figure decoration has a magical force, and it has a protective effect. The cloths from South Sumatra which were used in the death ritual was decorated by "the ship of the death". On the ship are the souls of the deceased. Similar decorations were found in the kettledrum's decoration. Other human decoration was found at Magetan, East Java. It represents a man with arms streched upwards and legs spread out. A similar relief was found at Tinggihari, South Sumatra. That kind of design were also woven into white cotton cloth with dark red background. The human figure standing between two "trees of life", with the legs spread out and the arms stretch upwards were carved surrounding the lid of a horizontal altar which was found in East Sumba. The characteristic of the faces are primitive and look like the mask design in Indonesian ornamentation.

Based on these data I concluded that the human decoration were very closed to the ancestor worship.

\section{Breasts decoration}

Ureasts decoration concluded in a human figure decoration. These decorations were found in one of the dolmen near Makatakere, and sculptured on the lid of a huge dolmen with 4 stone legs. I found a very similar decoration when I did a study on megalithic remains of Nias. In Nias island, the breasts decoration was carved on the lid of sitilubagi (a kind of stone seat for the bridegroom) 
and neobehe (a kind of stone seat for the bride). On the entrance of the traditional house at Kewar (West Timor), I found a breasts sculpture. According to the old guide and the people of Gomo Nias, breasts were the symbol of the fertility. In West Java (Sukabumi) Hasan Muarif Ambary from The National Research Centre of Archaeology found a very primitive statue with big breasts. He stated that this statute related to fertility especially in agriculture.

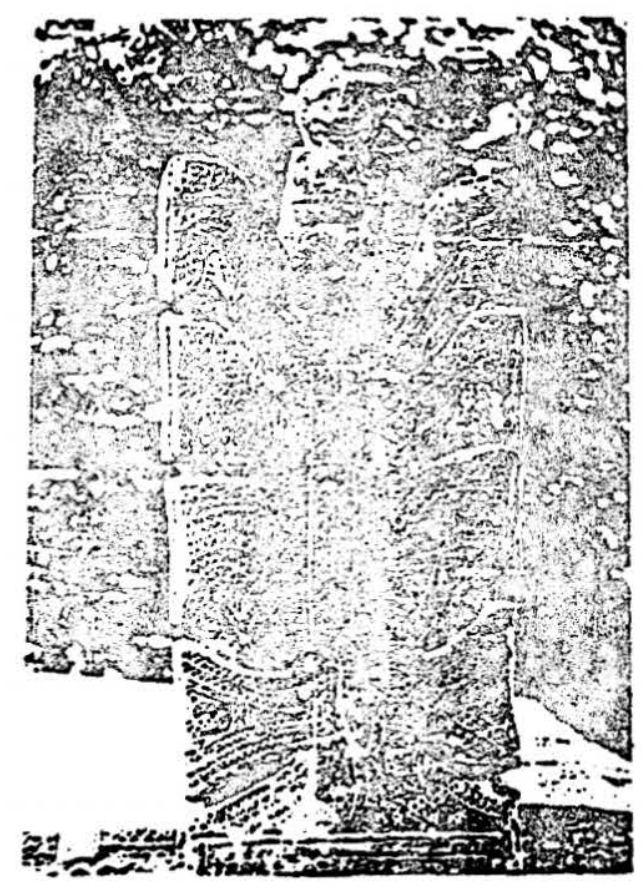

1. Human figure decoration, carved on the top of penji (menhir) from Preliu (Sumba).

2. Human figure decoration, sculptured on a dolmen.

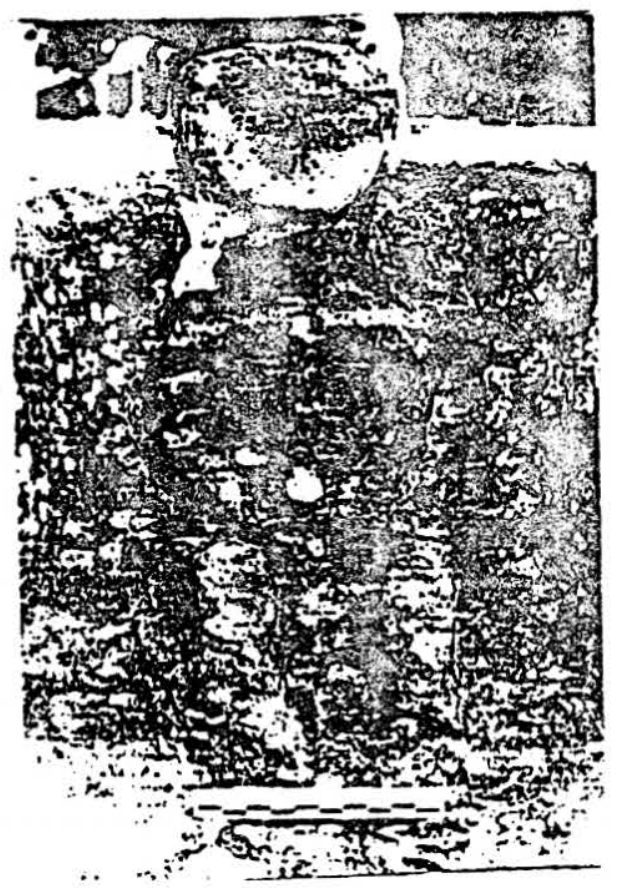




\section{Animal figure decoration}

In the megalithic finds in Sumba island we again encounter several verieties of the geometrical and animal figures designs. The main decoration which appeared on these megalithic remains is the animal figures. These decoration remind us somewhat of the design on traditional cloths from this area. The animals decoration motifs have a very close relation with the animal sacrificial.

The animal figures which were found on the megalithic objects in Sumba island consists of buffaloes, birds, elephants, crocodiles, snakes, monkeys, etc. They were sculptured on the dolmens and menhirs (penji). These animal decorations were usually very close to symbolic purposes. The people believed that horse or buffalo is a vehicle for the deceased when they went to their after world. Buffalo heads, were carved on the dolmens found at Riadi Umalolo, Praeliu, and Kawangu. The lizard or iguana are the very dominant designs in megalithic Sumba. Both of these animals were usually sculptured on horizontal stones (stone tables). According to the King of Pau, the souls of ancestors may enter into these creatures. The people believed that these ornaments were supposed to represent the incarnation of god or the ancestors. In traditional houses in Kewar (West Timor), lizard were sculptured on the walls or the entrance. Similar decorations were found during a survey carried out at Nias. The lizard reliefs were associated with geometric designs (circle, S-shaped, double spiral etc.).

Tortoise design is very well known in those parts of Indonesia where there has been little or none Hindu influence, for example in Nias, West Sumatra, Flores, Sumba, and Timor. These ornaments are sculptured on the lid of dolmen, the upright-stones, terrace grave, etc. A number of dolmens in tortoise shape were found at the megalithic site of "Kawangu" (East Sumba). One of the menhir found at Rindiumalolo, Melolo, East Sumba, depicted tortoise and other animal designs. According to the people from Sumba island, tortoise is a symbol of the ability (capability) and a fineness of the 
king. I would like to talk about the animal figure in detailed one by one.

\section{Buffalo motif}

Buffalo figures are a very universal motive, that can be found in many parts of Indonesia. This motif appeared in many varieties on prehistoric bronze objects, many megalithic monuments, and at the entrance of traditional houses. Buffaloes are domestic animals that have been known by the Indonesian ancentors since early neolithic period. The buffalo motifs were used by many people in different areas for example in Nias, Toraja, West Sumatra, Sumba, Flores, and Timor. During the ethnoarchaeological studies carried out in this area, many buffalo motifs were found. The same motifs found in the traditional houses of the living megalithic societies, usuailily were used as a symbol of status.

Buffalo motifs in the form of buffalo's heads and horns, can also be found on the lids of dolmen from West and East Sumba. In prehistoric society, buffaloes were considered sacrificial animals that were slaughtered in ceremonies. In the funeral feast of King Pau of East Sumba, buffaloes were slaughtered at the time when the deceased king will be inhumated. In Sumba, people thought that buffaloes were used to serve the deceased as a mount in the here after. In the village of Rindiumalolo, East Sumba, a huge dolmen was decorated with buffalo's head.

In describing the relation meaning between the dolmen and buffalo, Van Heekeren mentioned that dolmens were used as sacrificial altars or memorials; menhirs, obelisks of wood or stone, sometimes in rows or circle, the intervening space often being used as a place of assembly or for dancing, and stone seats consisting of a horizontal stone and one or more vertical ones as back supports are intended to the use of prominent living people and the souls of the dead. $\mathrm{He}$ also mentioned that festivities centre was around the sacrifice of cattle, because only he who has made such sacrifice when he 
was alive shall, when he dies, be allowed to enter the realm of the dead unpunished and unscathed, protected as he will be against the dangers of the hereafter by the magical powers of the buffaloes liberated during the sacrifice, ........ (Van Heekeren, 1958: 44). Alive megalithic culture is found among the Sa'dan people of Toraja, who are still erecting menhirs in rows or circles by way of memorial stones, and among whom the sacrificial slaughter of buffaloes is even until today the central feature at funeral festivities (Van Heekeren, 1958).

The excavation on the dolmen graves at Pakauman, Bondowoso, carried out by Willems yielded a larger number of potsherds of Chinese porcelain. Associated with the postsherds he found a few crown of human teeth and teeth of some kind of domestic horned cattle (Van Heekeren, 1958). It is possible that in funerary ceremonies a kind of domestic horned cattle were slaughtered for religius purpose (Willems, 1938).

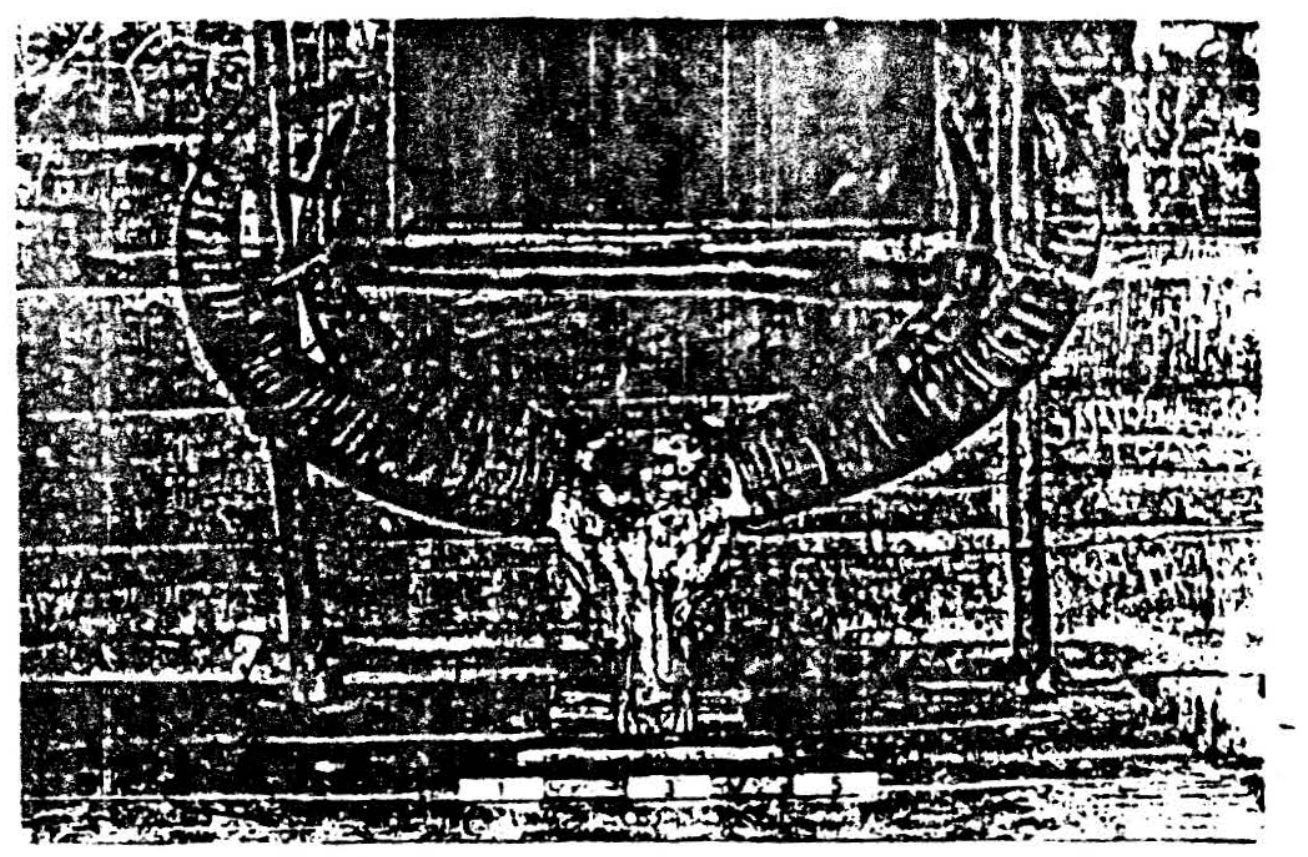

3. Buffulo motif, used as a decoration on the entrance of a traditional house. 


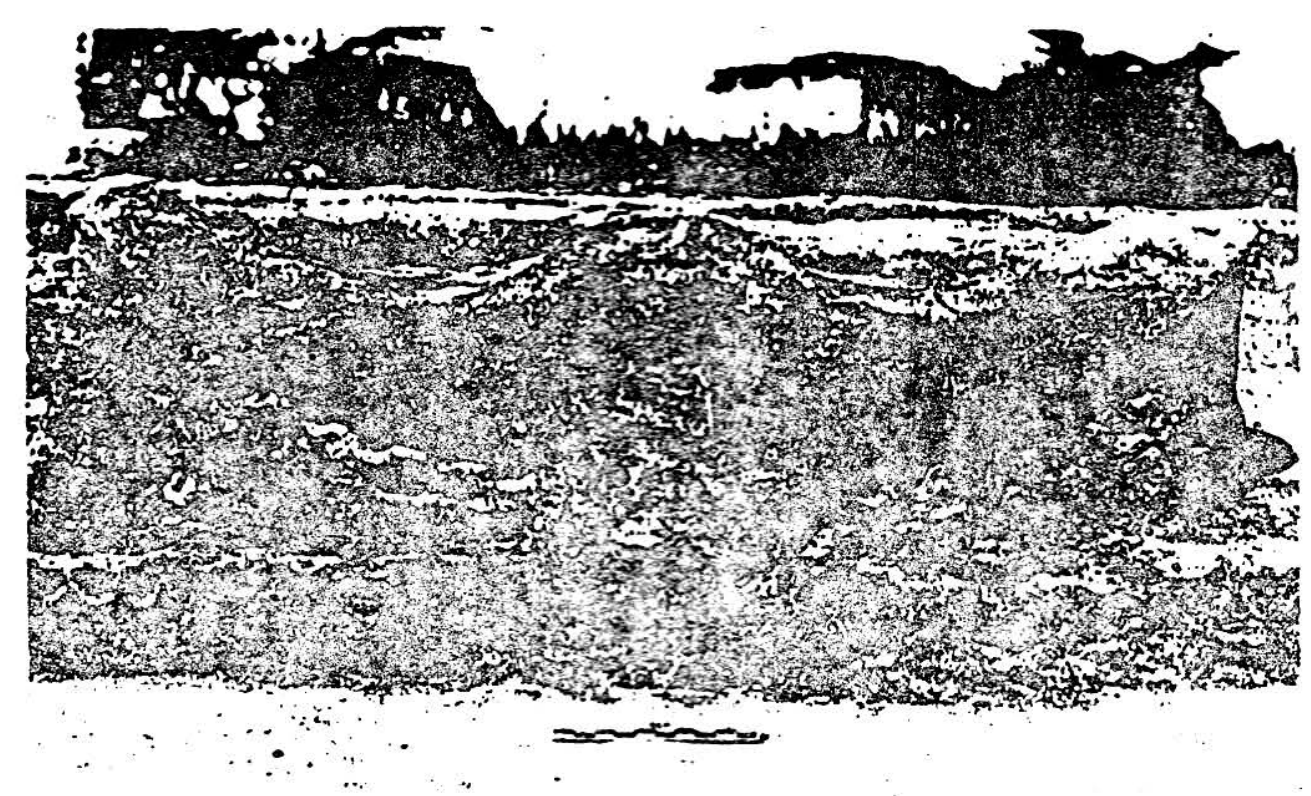

4. Horn decoration, carved on a dolmen's lid.

\section{Horse decoration}

The horse as well as the buffalo is a domestic and sacrifice animal. Sumba is a horse-breeding country, so that we need not wonder if in this island varieties horse decorations were found. In prehistoric period the horse decoration were found on many objects such as the tympanon of kettle-drums, traditional cloths with prehistoric style design, and on the megalithic objects, etc. The background and function of these decoration maybe similar to the buffalo motif. Horse were slaughtered during ceremonies. According to my guide, before the "pulling stone" ceremony, horses were slaughtered for protection against the evil and giving such welfare for workers. On the tympanon of the kettle-drum from Sangeang, a number of horses decoration were drawn in a row. Human figure riding on the horse with a very simple shape was supposed to be a soul of the deceased when he went to the hereafter. A number of horse heads decoration were found in East Sumba, and stylished horse decoration were found on traditional 
clothes. On the Penji or upright-stone found at Pau there was a horse decoration to sacrifice and were used as a mount to reach the hereafter.

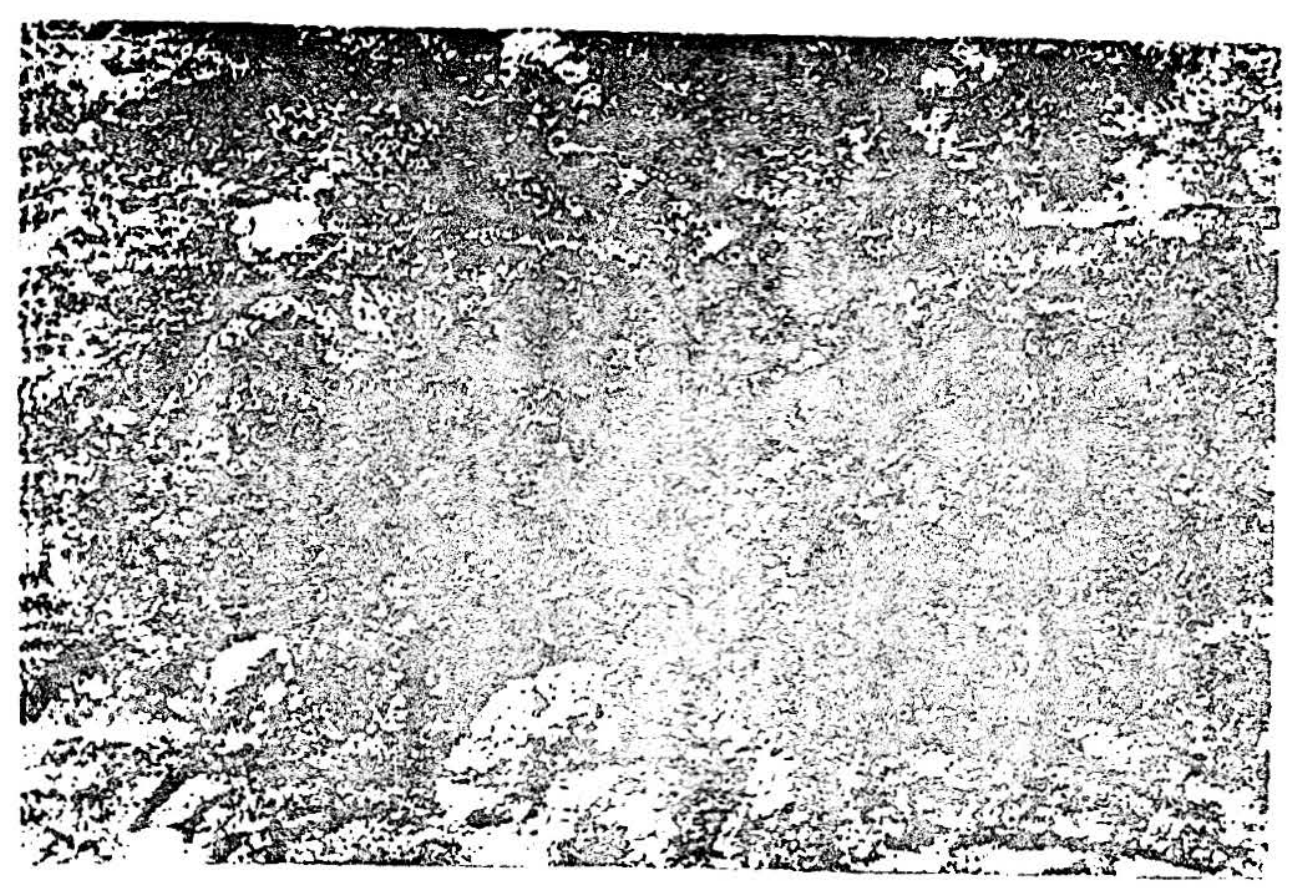

5. Horse decoration, found on a dolmen's Lid. lid.

\section{Rooster decoration}

Rooster decorations are the universal motif in the living megalithic tradition. They! were found in Nias, Toraja, Sumba. This decoration has a very close relation with courage or defying death. On the top of the upright stone in Cisarahili (South Nias), there is a stylished rooster design. Many parts of dolmens and penjis in Sumba island were decorated with roosters. Roosters (the cock) were usually slaughtered in ceremonies, and aiso drawn in traditional woven clothes. According to the people of Pau and the people of Cisarahili Gomo, rooster decorations were used as a symbol of force or courage. In European symbology, rcosters are related to the sun, because they crows about the hour of sunrise (Van der Hoop, 1949). 


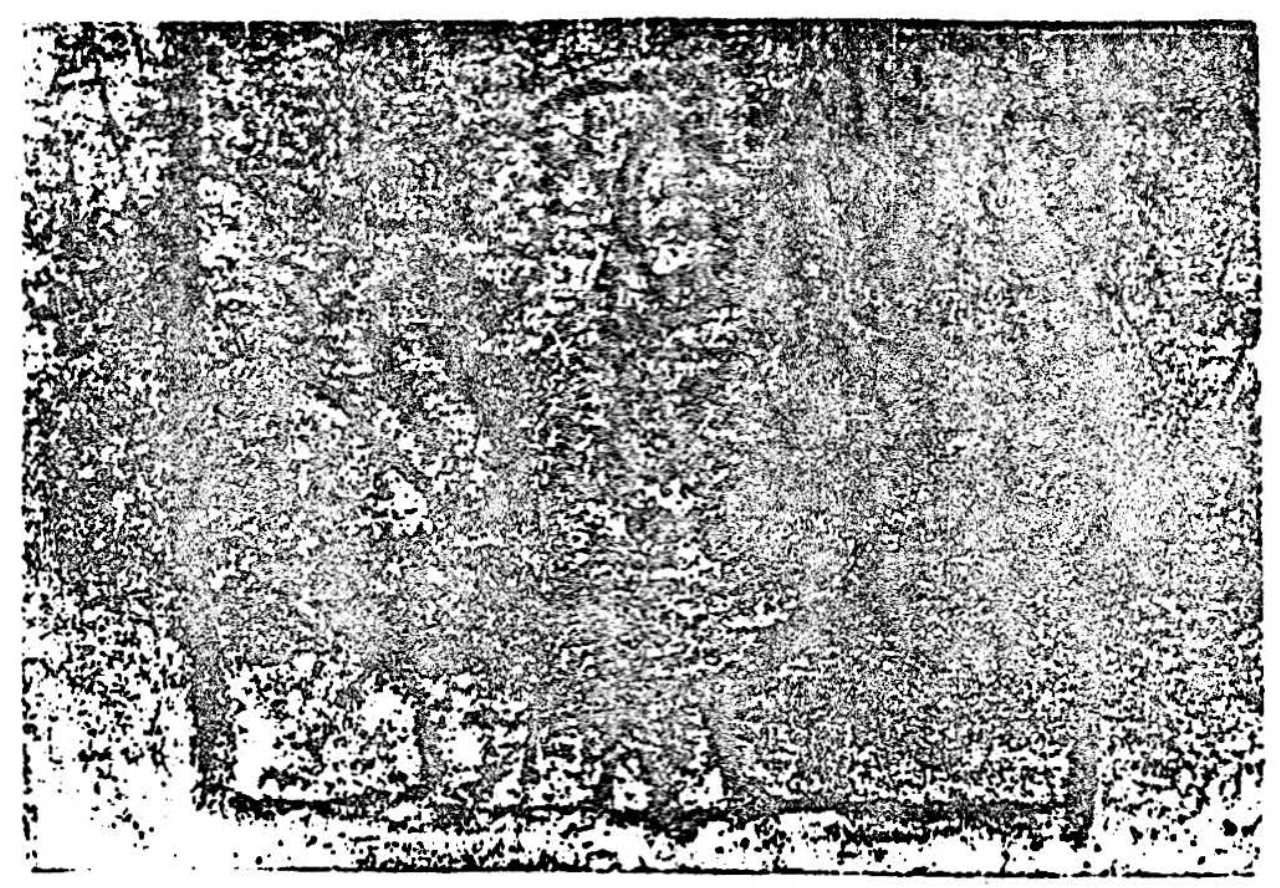

7. Elephant figure decoration.

\section{Elephant decoration}

Elephant decorations were carved on the penjis (upright stone) from Pau. There is no evidence about the existence of elephant during the megalithic period in Sumba island. That is why the elephant decoration was a very interesting feature. Now the important one is to understand the background of the elephant decoration. A number of elephant decorations were found on megalithic objects from South Sumatra (on the relief of Batu Gajah), tradition woven clothes with prehistoric style from Sumba, woven clothes with prehistoric decoration from Ranau etc. Elephant figures were found in the megalithic sites of Pasemah (South Sumatra). In Tinggihari I found a human figure statues that were depicted riding elephants. On woven clothes from a stylished elephant was drawn beside the animal look like a bird. On the back of the elephant, stand a stylished human figure which supposed to portrayed the soul bound for heaven. S. Suleiman assumed that elephant decoration is not a vehicle of the deceased. 


\section{Reptile decoration}

In the megalithic objects of East and West Sumba, quite often we find ornamental animal designs which represent small lizard or the iguana/crocodile. Some lizard decorations were carved on dolmens found in both regions, East and West Sumba. Lizard decorations were also found on the dolmens and penjis (uprightstone). On the penji from Pau, I saw a very fine and smooth crocodile carving. The King Pau from Melolo, East Sumba, mentioned that this decoration represented the red crocodile, a symbol of the King's ability.

In his book, The megalithic finds in Central Celebes W.J. Perry reported that in the district of Napu (Poso), elliptical, and shallow stone vats, some decorated with engraved animal figures, among which some lizards, can be recognized. Both Kruyt and Walter Kaudem have published good illustrations (Kruyt, 1932; Walter Kaudern, 1938). Stone vat is a high cylindrical stone coffin with a $150-250 \mathrm{~cm}$ in diameter and $250-300 \mathrm{~cm}$ high. It was used as a plural buria!. At the megalithic site at Padang Tumpuara there are stone vats containing more than eight skulls. One of them yielded the complete skeletons of a man and a woman.

in the rnegalithic culture in Indonesia, W.J. Perry said: "The chief of Kupang in Timor are said to be descended from crocodiles, and the carved crocodiles on the back of the stones seats of chiefs in Nias suggest a close relationship between these creatures and the chief" (Perry, 1918).

On the door of a rice shed from the living megalithic site in Batak and on the entrances of traditional houses from Kewar (West Timor). the lizard decorations were carved (Van der Hoop, 1941, The Report of the megalithic studied in West Timor, NRCA).

On the path of stone terrace at Gomo and on the lid of sitilubagi from Sifarauasi Gomo stylized lizards were carved between the panels of geometric decoration. 
Perry mentioned that lizards and crocodiles sometimes represents the incarnation of a deity or the soul of the deceased. These animals indicated that they were closely related to the funerary burial on the megalithic tradition.

\section{Other animal decoration}

Other animal decorations which were found on the megalithic remains from Sumba island consist of: canary (bird), varieties of fishes, pigs, dogs, monkeys, cats, etc.

\section{The geometrical decoration}

Geometrical ornament in many varieties are usually found on many decorated dolmen's lid. It can be found at many megalithic sites in Indonesia, for example in Nias Island, Toraja (South Sulawesi), Mahat (West Sumatra), West Timor, and Sumba. In the bronze iron age, geometrical decoration were very dominant, and often carved on the tympanons of kettledrums, bronze urns, ceremonial axes, and bronze vessels. The excavation carried out on the coastal burial sites at Plawangan, Gilimanuk, and Melolo, yielded many potteries with geometrical decoration.

Many scholars assume that the geometrical ornament plays an important role in the neolithic and paleometallic periods. The evidences that were found by Ayu Kusumawati, Bagyo Prasetyo, I Dewa Kompiang Gede and the author at many sites in Sumba Island, indicated that the geometrical ornaments from the living megalithic culture in Sumba Island were not related to the religius background.

The geometrical ornaments consists of :

\section{- Double spiral decoration}

The double spiral ornament were usually carved on the lid of dolmens and on upright-stones (menhirs). This decoration were also found on the bronze urn from Kerinci and on the bronze 
vessel from Madura (Van Heekeren, 1958). On upright stone from West Timor, a very fine and smooth double spiral design was found on pillar (a kind of upright-stone; Archaeological research presented by the team from NRCA on 1983). The background and the function of this design are still in question up to the present time. In Nias Island, the double spiral design is assumed as a vahasara dede, a symbol of unity.

\section{- Meander decoration}

The meander decoration are the universal decoration in the "living megalithic tradition". It appears on any dolmen in both West and East Sumba. This decoration were usually carved in horizontal parallel line motives and was intended to decorate the lid of horizontal stone (stone table). The meander motive in the megalithic objects from Sumba consists of various shaped. The meander decoration is very dominant and well-known in the paleometallic period. The whole length of the meander was divided into two parts, the inside were decorated with triangle design.

- Tumpal decoration (triangle decoration)

The tumpal or triangle decoration were used to decorate the lids of stone tables and the legs of dolmens. On a number of penji (upright-stone) at the entrance of a traditional house, I found a tumpal which in this case were filled in with a stylized form of floral decoration. A series of tumpal design were usually carved along the lids of the dolmens, and usually bordered by the parallel lines. In the Nias design art, the tumpal decoration are mentioned as neovulayo design (a symbol of power) or magical power.

The tumpal (triangle) decoration were also found on traditional clothes from Sumba, usually used as a shrouds, before the corpse was inhumated.

- Other geometric decorations are: tangets, a series of circle, circlets joined by tangets, etc. 
Some evidences from the living megalithic tradition in Sumba show that the geometrical decoration were usually used on artistic purpose. Animal figure decorations were used as a symbol of capability of the king, and the human figure decoration maybe related to the religius purpose or representing the soul of the deceased.

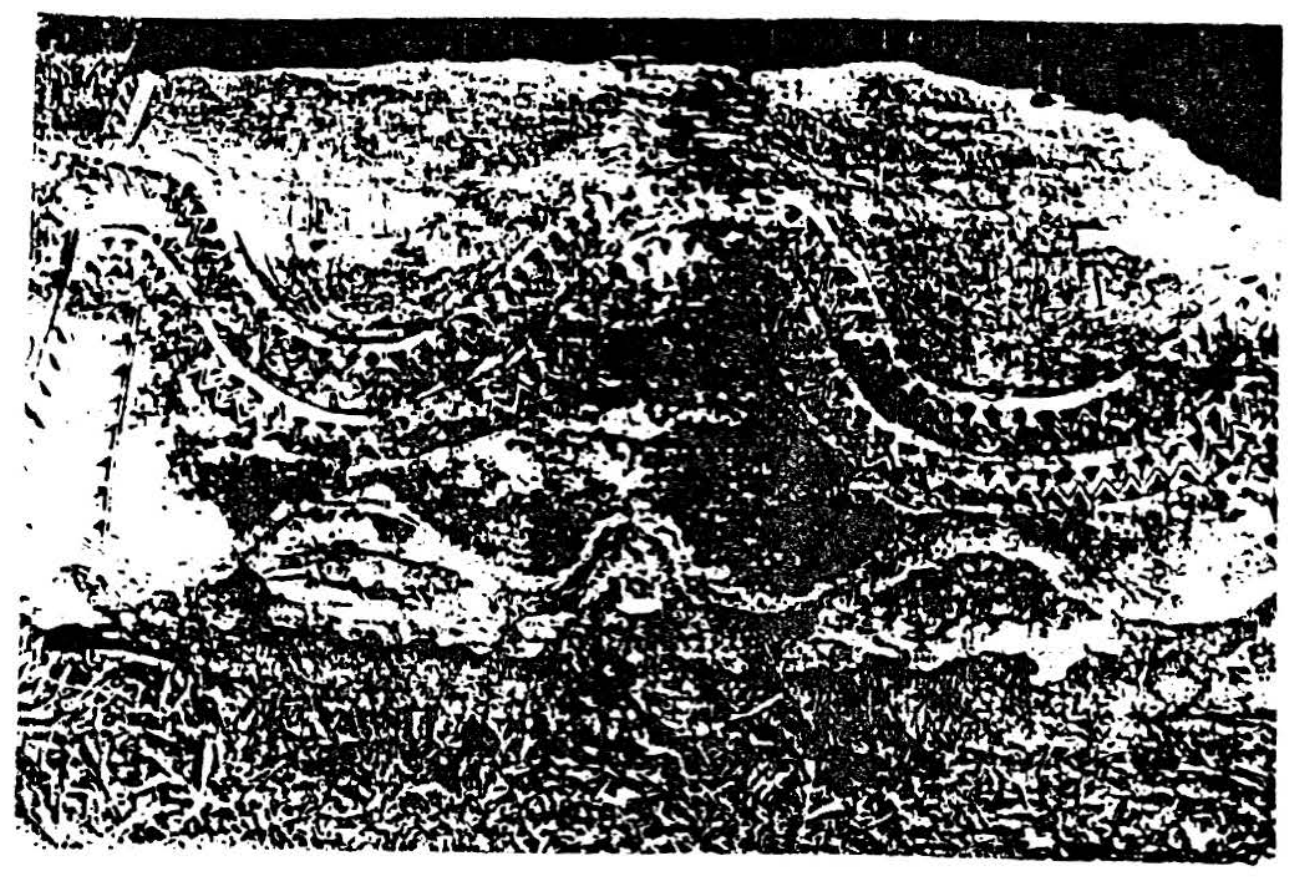

9. Meander decoration, found on a dolmen's lid. 


\section{DAFTAR PUSTAKA}

Heekeren, HR van 1931 "Megalitische Overbijfselen bij Bondowoso", Djawa Tijdschrift van het Java-Instituut.

Heekeren, HR van 1958 "The Bronze-Iron age of Indonesia", VKI XXII. 'sGravenhage. Martinus Nijhoff.

Heekeren, HR van 1960 Penghidupan dalam Zaman Prasejarah di Indonesia. Terjemahan Moh. Amir Sutaarga, Jakarta.

Heine Geldern, R. von 1945 "Prehistoric R.esearch in the Netherlands Indies", Science and Scientists in the Netherlands Indies, New York.

Hoop, AN.J. Th a Th van der. 1932 Megalithic Remains in South Sumatra, Zuthpen.

Hoop, AN.J. Th a Th van der. 1935 "Steenkistgraven in Goenoeng Kidul" IBG, deel LXXV, Batavia.

Hoop, AN.J. Th a Th van der. 1938 "De Praehistorie" dalam F.W. Stapel:

Geschiedenis van Nederlandsch-Indie, deel I, Amsterdam.

Hoop, AN.J. Th a Th van der. 1949 Indonesische Siermotieven (R. agamRagam Perhiasan Indonesia, Indonesian Ornamental Design), Koninklijk Bataviaasch Genootschap van Kunsten en Getenschappen. Kaudern, Walter,

Hoop, AN.J. Th a Th van der. 1938 Megalithic Finds in Central Celebes, Ethnographical Studies in Celebes, Elanders Boktryckeri Goteborg: Elanders Boktryckeri Aktiebolg.

Mude, H.B. 1976 An Introduction to Unique Culture of Sumba, unpublished.

Perry, W.J. 1918 The Megalithic Culture in Indonesia, Manchester.

Soejono, R.P. 1977 Sistim -sistim Penguburan pada akhir Masa Prasejarah di Bah (Disertasi) Jakarta: Universitas Indonesia

Willems, W.J.A 1938 "Het Onderzoek der Megalithen te Pakaoeman bij Bondowoso Oudheidkundige Dienst in Nederlandsch-Indie. Rapporten no 8. 